\title{
Hygiene Factor Analysis and Employee Satisfaction PT. PLN West Flores Area in Ende
}

\author{
Yulita Londa, \\ Accounting Study Program \\ Flores University, Indonesia
selolitalonda@yahoo.com \\ Flores University, Indonesia
selolitalonda@yahoo.com
}

\begin{abstract}
The purpose of this study was to analyze the Hygiene factors and job satisfaction of employees of PT. PLN West Flores on Eltari Ende road. The results of this analysis are expected to be useful for management in making strategic decisions related to human resource management. The factors analyzed are work environment factors, salary or wages, company policies, methods of supervision, interpersonal relationships, job security, and job satisfaction.

This type of research is descriptive qualitative. The type of data used is qualitative data and quantitative data. The primary and secondary data sources analyzed were obtained by using means of conduct interviews, observation, and distributing questionnaires. The population in this study amounted to 276 people spread over 4 (four) Customer Service Units in 5 (five) districts. The minimum sample size used is 74 respondents calculated using the Slovin formula with an error rate of $10 \%$. The
\end{abstract}

\section{INTRODUCTION}

During the current Covid-19 pandemic, most companies experienced difficulties in running their business. Companies are forced to make difficult decisions by laying off most of the employees. Attempts to achieve company goals

\author{
Santi Permatasari \\ Management Study Program \\ Flores University, Indonesia
}

sampling technique used non-random sampling using quota sampling. The data collection technique used a questionnaire distributed to 4 (four) customer service units located in 5 districts in the western part of Flores. Respondents' answers were measured using a 5 Likert scale. Also addition, researchers classified all respondents' answers to open questions contained in the same questionnaire. The researcher analyzed the respondents' answers through the calculation of the frequency of answers and the results of descriptive statistical calculations.

The results show that the Hygiene Factor and Job Satisfaction are good, this can be seen from the average answers to the factors of the work environment, salary or wages, company policies, methods of supervision, interpersonal relationships and job security are above the theoretical average. Conciseness, the results of the frequency distribution analysis of all the factors studied for the total answers agree and strongly agree, the range is $66 \%$ to $95 \%$.

Keywords: Hygiene factors, Job satisfaction

by utilizing all the resources or working capital owned by the company are disrupted. Some other companies decide that their employees work from home (work from home) with a flexible performance appraisal system so that the correctness and honesty of performance are still 
in doubt. By following the demands of quality human resources in the era of the 4.0 industrial revolution marked by technological developments, human resources are required to master technology that supports the work from home process both online and offline.

Managing human resources is not an easy thing. Humans are a unique element and have different characteristics from one another. Humans have different attitudes, and behaviors because these differences tend to create gaps and groupings. Therefore, reliable management is needed to anticipate all of this, so that both personal and corporate interests can be achieved.[1]

Employees are the main asset owned by profit oriented organizations that must be maintained to achieve organizational goals and objectives. This is because employees are planners, controllers, and active actors of every company activity.[2] High work performance will be achieved if employees have job satisfaction.

States that to be able to provide high job satisfaction to employees, company leaders must find out what factors affect employee job satisfaction. According to the two-factor theory, it is said that the factors that affect employee job satisfaction include work environment factors, salary or wages, company policies, supervision methods, interpersonal relationships, and job security. These factors are better known as Hygiene Factors.[3]

PLN West Flores Region is domiciled in Ende, serving the distribution of electrical energy in the districts of Ende, Nagekeo, Ngada, Manggarai Timur, Manggarai, and Manggarai Barat, and is divided into 4 Customer Service Units (UPP): (1) UPP Ende, (2) UPP Bajawa, (3) UPP Manggarai and (4) UPP Labuan Bajo. A large service area requires a relatively large number of workers/employees.

The factors that will be examined in this research are work environment factors, salary/wages, company policies, supervision methods, interpersonal relationships, job security, and job satisfaction. The research objective with this survey method is to analyze the hygiene factors and job satisfaction of employees of PT. PLN West Flores in Ende. The results of the analysis of hygiene factors and job satisfaction are expected to be useful for PLN Management in making strategic decisions related to human resource management.

\section{LITERATURE REVIEW}

Research related to hygiene factors and job satisfaction has been done by many previous researchers. Research by [4] shows that hygiene factors have a positive effect with different strengths on job satisfaction. Meanwhile, other studies have shown that hygiene factors provide high job satisfaction to employees.[5][6][7] Other studies have shown that salary and promotion have a positive and significant effect on employee job satisfaction. [8] A pleasant work environment has a significant effect on job satisfaction. Participation in making decisions has no direct effect on job satisfaction. [9] Job satisfaction has no direct effect on employee turnover rates. However, it has contributed to employee turnover in the company.[10][11] The results of [12] research show that hygiene factors have a significant effect on job satisfaction.

\section{A. Hygiene factors}

Hygiene factors can prevent job dissatisfaction and as a deterrent to negative cooperation in the workplace. Herzberg Hygiene factors consist of factors of the work environment, salary, company policy, methods of supervision, interpersonal relationships, and job security[3]. A work environment is a place where people work or a place to do work. [13] A safe and comfortable environment will be able to make work easier to do and get good results that are expected by the company. The work environment is said to be good if the workers can carry out their work safely, healthily, and comfortably because a bad work environment can also have a bad impact on the company because it makes workers unable to work optimally. [9] [14][15][16]

A Salary is a form of remuneration paid by the company to employees in the form of money, for services that have been provided. Often management tries to increase employee job satisfaction through improving salaries and wages, this may still be acceptable at a certain level because with this salary employees can make ends meet. But the fact is that a high salary 
does not always make an employee feel satisfied with his job. [5], [8], [17]

Company policy is a guideline that defines laws, regulations, goals, which can be used by the leadership in making decisions. Company policies were made to ensure the smooth operation of the company. [15]

Apart from that, the method of supervision, interpersonal relations, and job security must also receive attention from leadership because it is closely related to employee job satisfaction. Employees will feel guided and cared for by the leadership if the leadership often supervises what the employees have done.[4][5][6] A harmonious relationship between superiors and subordinates and good job security can create a comfortable, pleasant work atmosphere and can prevent employees from feeling dissatisfied.

\section{B. Job satisfaction}

Job satisfaction is defined as a pleasant or unpleasant situation in which an employee views his or her job. Job satisfaction describes a person's feelings about his job and will appear through the individual's attitude at work and everything he faces. Job satisfaction is a person's perspective, both positive and negative about their work. ${ }^{[13]}$ The more aspects of work that are in accordance with the wishes of the individual, the individual will feel more satisfied with his job. Job satisfaction felt by a person also varies widely depending on the time, individual characteristics, attitudes, behavior, and work environment.

The symptom that causes poor working conditions in an organization is low job satisfaction. Companies must strive to improve the job satisfaction of their employees. If employees have high job satisfaction, then the company can retain its employees, and employees can also serve as good primary partners in supporting the company's success. High job satisfaction felt by employees will have a good impact on work productivity, which in turn can help the company achieve its targeted goals.

\section{RESEARCH METHODOLOGY}

The hygiene factor survey was carried out at the West Flores PLN office on Eltari Street, in Ende. This type of research is descriptive research. Descriptive is a study conducted to determine the value of independent variables, either one or more variables (independent variables).[18] The population in this study amounted to 276 people and a sample size of 74 people. The sampling technique used non-random sampling using quota sampling. The type of data used is qualitative data and quantitative data. Meanwhile, the data source is the primary data source. The data collection technique used a questionnaire and the data analysis technique was descriptive quantitative.

\section{DATA ANALYSIS AND INTERPRETATION}

A. Respondent Demographics

Respondents who became the sample in this study were 80 people consisting of 73 men $(91 \%)$ and 7 women $(9 \%)$. Respondents aged 15 to 30 years amounted to 32 people (40\%), 12 people aged 36 to 45 years $(45 \%)$, and aged 45 to 60 years amounted to 9 people $(15 \%)$. The educational backgrounds of the respondents included 58 high school and vocational school students $(72.50 \%), 7$ D3 students (7.50\%), and 16 undergraduate students (20\%). Respondents who had a work period of 1 to 5 years 24 people (30\%), a work period of 6 to 10 years 25 people $(31 \%)$, and a work period of more than 10 years amounted to 31 people (39\%). In addition, there were 47 respondents $(59 \%)$ who became permanent employees and 33 non-permanent employees $(41 \%)$. The number of respondents who held positions was 55 people $(69 \%)$ and 25 staff members $(31 \%)$.

\section{B. Descriptive statistics}

In this study, descriptive statistics are used to provide an overview of respondents' responses regarding occupational health factors (hygiene factors). This picture can be seen in table 1 . Descriptive statistical recapitulation in table 1 shows that the average value of the real respondents' answers for environmental factors, salaries, company policies, methods of supervision, interpersonal relationships, job security, and job satisfaction is higher than the theoretical average. It can be said that the Hygiene Factor at PT PLN West Flores in Ende is in good condition. Job satisfaction is an emotional attitude that is fun and loves work which is reflected in the attitude of discipline, work morale, and work performance. ${ }^{[5][8][16]}$ 
Table 1.

\section{DESCRIPTIVE STATISTICAL RECAPITULATION}

\begin{tabular}{|c|c|c|c|c|c|}
\hline \multirow{3}{*}{ Var } & \multicolumn{4}{|c|}{ Respondents' Answers } & \multirow{3}{*}{$\begin{array}{l}\text { Standa } \\
\mathbf{r} \\
\text { Deviati }\end{array}$} \\
\hline & \multicolumn{2}{|c|}{ Range } & \multicolumn{2}{|c|}{ Mean } & \\
\hline & Teo & Actual & Teo & Actual & \\
\hline FLK & $\begin{array}{l}17 \\
\mathrm{~s} /\end{array}$ & $46 \mathrm{~s} / \mathrm{d}$ & & 64,12 & 8,124 \\
\hline FG & $\begin{array}{c}6 \mathrm{~s} / \mathrm{d} \\
30\end{array}$ & $\begin{array}{c}14 \mathrm{~s} / \mathrm{d} \\
30\end{array}$ & 18 & 23,41 & 3,416 \\
\hline FKP & $\begin{array}{c}7 \mathrm{~s} / \mathrm{d} \\
35\end{array}$ & $\begin{array}{c}13 \mathrm{~s} / \mathrm{d} \\
35\end{array}$ & 21 & 26,2 & 4,401 \\
\hline FMS & $\begin{array}{c}6 \mathrm{~s} / \mathrm{d} \\
30\end{array}$ & $\begin{array}{c}15 \mathrm{~s} / \mathrm{d} \\
30\end{array}$ & 18 & 23,08 & 3,261 \\
\hline FHAP & $\begin{array}{c}7 \mathrm{~s} / \mathrm{d} \\
35\end{array}$ & $\begin{array}{c}18 \mathrm{~s} / \mathrm{d} \\
35\end{array}$ & 21 & 27,69 & 3,631 \\
\hline FKK & $\begin{array}{c}7 \mathrm{~s} / \mathrm{d} \\
35\end{array}$ & $\begin{array}{c}16 \mathrm{~s} / \mathrm{d} \\
35\end{array}$ & 21 & 27,66 & 3,894 \\
\hline FKKER & $\begin{array}{c}10 \\
\mathrm{~s} / \\
\mathrm{d}\end{array}$ & $\begin{array}{c}25 \mathrm{~s} / \mathrm{d} \\
50\end{array}$ & 30 & 39,31 & 4,828 \\
\hline
\end{tabular}

Source: Primary Data of SPSS Results Version 25, 2020

\section{Analysis of Hygiene Factors and Job Satisfaction}

Another way to determine the tendency of the respondent's answers is to do an analysis using the frequency distribution of each question item for each factor. This is done to see whether the meaning is almost the same as the descriptive statistical calculation results. The analysis will be complemented by a chart. The analysis of each item will be explained as follows:

\section{Work Environment Factors}

The results of the frequency distribution analysis of work environment factors are as follows: (1) Respondents answers strongly disagree $2 \%,(2) 7 \%$ disagree, (3) doubt $11 \%$, (4)

agree $59 \%$, and (5) strongly agree $22 \%$. The highest percentage is $59 \%$ in the agreed answer, it means that the work environment at PT. PLN West Flores Region is good, but there are still respondents who answered strongly disagree $2 \%$ and $7 \%$ disagree. A neatly decorated work environment, away from noise, fresh and healthy air makes employees feel comfortable at work, which in turn makes employees feel satisfied at work and can further increase employee productivity.

\section{Salary/Wage Factor}

The results of the frequency distribution analysis of the salary/wage factors are as follows: (1) $5 \%$ strongly disagree, (2) $8 \%$ disagree, (3) doubt $11 \%$, (4) agree 59\%, and (5) strongly agree $18 \%$. The highest percentage is $59 \%$ in agreeing for answers. From the answers strongly disagree $8 \%$, and $10 \%$ disagree, respondents stated that 13 respondents were not satisfied with the salary received, the salary did not match the responsibilities borne by 13 respondents and 21 respondents stated that PT. PLN West Flores did not provide additional wages if the working time exceeds the rules applicable in the company.

\section{Company Policy Factors}

The results of the frequency distribution analysis of the company policy factors are as follows: (1) Strongly disagree 5\%, (2) disagree 14\%, (3) neutral $15 \%$, (4) agree $53 \%$, (5) strongly agree $13 \%$. The answers agree and strongly agree with a total of $66 \%$, meaning that the majority of employees are satisfied with the policies implemented by the company. Even so, there are $15 \%$, who do not show attitude and $19 \%$ are not satisfied with company policies.

\section{Supervising Method Factors}

The results of the frequency distribution analysis of environmental factors are as follows: (1) $1 \%$ strongly disagree, (2) disagree 3\%, (3) neutral $7 \%$, (4) agree $66 \%,(5)$ strongly agree $22 \%$. Total answers agree and strongly agree $84 \%$, this means that PLN has good supervision methods. The method of supervision can be done directly or indirectly. Supervision that is carried out periodically or routinely will reduce opportunities for employees to make mistakes that can cause losses to the company.

\section{Interpersonal Relationship Factors}

The results of the frequency distribution analysis of the interpersonal relationship factors are as follows: (1) $1 \%$ strongly disagree, (2) disagree $1 \%$, (3) doubt $4 \%$, (4) agree $72.5 \%$, (5) strongly agree $22.5 \%$. This shows that the relationship between employees and other employees as well as between employees and leaders is good and there are no problems. With good interpersonal relationships, internal conflicts can be avoided. 


\section{Work Security Factor}

The results of the frequency distribution analysis of job safety factors are as follows: (1) Strongly disagree $2 \%$, (2) disagree $1 \%$, (3) neutral $11 \%$, (4) agree $67 \%$, (5) strongly agree $20 \%$. The highest percentage answered agree, very agree $87 \%$. This shows that job security at PT. PLN Ende is good or employees feel safe at work.

\section{Job Satisfaction Factor}

The results of the frequency distribution analysis of the job satisfaction factors are as follows: (1) Strongly disagree $2 \%$, (2) disagree $4 \%$, (3) neutral $10 \%$, (4) agree $68 \%$, (4) strongly agree $16 \%$. The highest percentage of answers agreed and strongly agreed with a total of $84 \%$. This shows that the employees of PT. PLN West Flores Region is satisfied in carrying out its work.

\section{CONCLUSION}

Based on the results of descriptive statistical data processing and frequency distribution of respondents' answers regarding the factors (hygiene factors) under study, it can be concluded that the Hygiene Factors of PT. PLN West Flores in Ende is good and employees feel satisfied at work even though there are still employees who are not satisfied in carrying out their work. Suggestions for further researchers in conducting research need to add other variables related to job satisfaction, for example, motivation variables.

\section{REFERENCES}

Arfan Ikhsan, Sumberdaya Manusia Suatu Tinjauan Penilaian Modal Manusia, First Edit. Jogjakarta: Graha Ilmu, 2018.

[2] B. Ruswandi, "Analisis kepuasan kerja karyawan dinilai dari hygiene factor dan motivation factor dengan metode second order confirmatory factor analysis," LOGIKA, vol. 6, no. 2, pp. 96-111, 2016.

[3] Stephen P. Robbins \& Timothy A. Judge, "MAN 3240 - Applied Organizational Behavior (New / Master) - Coronel Title : Essentials of Organizational Behavior, 11th edition," 2012.

[4] M. Rupasinghe and N. Morais, "A Study on the Effect of the Hygiene Factors onOverall Job Satisfaction of the Employees in Airline industry," Colombo J. Adv. Res., vol. 1, no. 1, pp. 147-161, 2019.

[5] T. Teck-Hong and A. Waheed, "Herzberg's motivation-hygiene theory and job satisfaction in the Malaysian retail sector: The mediating effect of love of money," Asian Acad. Manag. J., vol. 16, no. 1, pp. 73-94, 2011.

[6] C. Holmberg, I. Sobis, and E. Carlström, "Job Satisfaction Among Swedish Mental Health Nursing Staff: A Cross- Sectional Survey," International Journal of Public Administration, 2016.

[7] A. M.Sankar MBA.,M.Phil., "Impact of Hygiene Factors on Employee Retention : Experimental Study on Paper Industry," Indian J. Manag. Sciense, vol. V, no.

June 2015, p. 2249, 2015.

[8] N. Mustapha, "The Influence of Renumeration Package and Promotion Opportunity on Job
Satisfaction Among Lecturers in Malaysia," GSTF J. Bus.

Rev., vol. 2, no. 3, pp. 212-2016, 2013, doi: 10.5176/2010-4804.

[9] A. Waqas et al. "Factors Influencing Job Satisfaction and Its Impact on Job Loyalty," Int. J. Learn. Dev., vol. 4, no. 2, pp. 141-161, 2014, doi:

10.5296/ijld.v4i2.6095.

[10] S. Jarupathirun and M. De Gennaro, "Factors of work satisfaction and their influence on employee turnover in Bangkok, Thailand," Int. J. Technol., vol. 9, no. 7, pp. 1460-1468, 2018, doi:

Yue, "Job 10.14716/ijtech.v9i7.1650. [11] D. R. Jusoh and W.

Satisfaction and Turnover Intention Influence of Organization Performance: Experience At Higher Education Institution in Shanghai China," J. Educ. Soc. Sci., vol. 13, no. 1, pp. 123-128,

2019, [Online]. Available: https://www.jesoc.com/wpcontent/uploads/2019/09/KC13_025.pdf.

[12] Stevianus, "Pengaruh Faktor Hygiene dan Motivatir terhadap Kepuasan Kerja Karyawan Pada PT. Rianto Prima Jaya,"

J. Ekon. Bisnis, vol. 20, no. 1, pp. 32-41, 2015.

[13] M. Ilham, "Pengertian Lingkungan Kerja Menurut Para Ahli Lengkap," 2020. https://materibelajar.co.id/pengertian- lingkungankerja-menurut-para-ahli/.

[14] R. Saeed, R. N. Lodhi, A. Iqbal, H. H. Nayyab, S. Mussawar, and S. Yaseen, "Factors influencing job satisfaction of employees in telecom sector of Pakistan," Middle East J. Sci. Res., vol. 16, no. 11, pp. 1476-1482, 2013, doi:

10.5829/idosi.mejsr.2013.16.11.12075.

[15] B. Raja Muhammad Ali and F. Ahmed Wajidi, "Factors Influencing Job Satisfaction in Public Healthcare Sector of Pakistan," Glob. J. Manag. Bus. Res. Adm. Manag., vol. 13, no. 8, 2013, [Online]. Available: https://scholar.google.co.id/scholar?hl=id \&as_sdt $=0 \% 2 \mathrm{C} 5 \& \mathrm{q}=$ environmental + fact ors+influencing+job+satisfaction\&btnG=

[16] Michele Wargo-Sugleris, "Title Job Satisfaction, Work Environment, and Successful Aging: Determinants to Remain in Older Acute Care Nurses," University of California, Los Angeles, 2015.

[17] H. W. Lee and M. C. Lin, "A study of salary satisfaction and job enthusiasm - mediating effects of psychological contract," Applied Financial Economics, vol. 24, no. 24. pp. 1577-1583, 2014, doi: 10.1080/09603107.2013.829197.

[18] Sugiyono, Metode penelitian kuantitatif kualitatif dan $r \& d$. Bandung: Alfabeta, 2010. 